\title{
Література
}

1. Дидактика средней школы / под ред. М. А. Данилова, М. Н. Скаткина. - М. : Просвещение, 1975. - 303 с. 2. Дидактика средней школы / под ред. М. Н. Скаткина. - [2-е изд.]. - М. : Просвещение, 1982. - 319 с. З. Загвязинский В. И. Педагогическое творчество учителя / В. И. Загвязинский. - М. : Педагогика, 1987. - 160 с. 4. Кларин М. В. Педагогическая технология в учебном процессе: Анализ зарубежного опыта / М. В. Кларин. - М. : Знание, 1989. - 80 с. 5. Кузьмина Н. В. Очерки психологии труда учителя / Н. В. Кузьмина. - Л. : Изд-во ЛГУ, 1967. 183 с. 6. Львова Ю. Л. Как рождается урок / Ю. Л. Львова. - М. : Знание, 1976. - 62 с. 7. Муравьева Г. Е. Подготовка студентов педвузов к проектированию процесса обучения на уроке: дис. ... канд. пед. наук / Г. Е. Муравьева. - М., 1990. - 175 с. 8. Сластенин В. А. Формирование личности учителя советской школы в процессе профессиональной подготовки / В. А. Сластенин. - М. : Просвещение, 1976. - 160 с.

Людмила Насілєнко

\section{ПЕДАГОГІЧНІ УМОВИ ФОРМУВАННЯ КОМУНІКАТИВНОЇ КОМПЕТЕНТНОСТІ МАЙБУТНІХ ЮРИСТІВ У ПРОЦЕСІ ВИВЧЕННЯ СПЕЦІАЛЬНИХ ДИСЦИПЛІН}

Насілєнко Л. А. Педагогічні умови формування комунікативної компетентності майбутніх юристів у процесі вивчення спеціальних дисциплін.

У статті на основі наукових джерел і досвіду викладання на юридичному факультеті окреслено педагогічні умови формування комунікативної компетентності майбутніх юристів. Увага акцентується, зокрема, на формуванні мотиваційно-ціннісного ставлення студентів до здійснення професійної комунікації під час занять із курсу «Українська мова за професійним спрямуванням», а також на збагаченні змісту спеціальних дисциплін інноваційними технологіями, що стимулює студентів до активної мовленнєвої діяльності.

Ключові слова: майбутній юрист, комунікативна компетентність, педагогічні умови, спеціальні дисципліни.

Насиленко Л. А. Педагогические условия формирования коммуникативной компетентности будущих юристов в процессе изучения специальных дисциплін.

В статье на основе научных работ и опыта преподавания на юридическом факультете представлены педагогические условия формирования коммуникативной компетентности будущих юристов. Внимание акцентируется в частности на формировании мотивационноценностного отношения студентов к совершению профессиональной коммуникации во время занятий по курсу «Украинский язык по профессиональному направлению», а также на усовершенствовании содержания специальных дисциплин инновационными технологиями, что стимулирует студентов к активной речевой деятельности.

Ключевые слова: будущий юрист, коммуникативная компетентность, педагогические условия, специальные дисциплины.

Nasilenko L. A. Pedagogical conditions of lawyers' communicative competence formation in the study of special subjects.

On the basis of scientific sources and teaching experience at the judicial faculty in the article are outlined pedagogical conditions of lawyers' communicative competence. Attention is paid in particular to the formation of motivational-value ratio of students to professional communication at the lessons of the course «Ukrainian language for professional purposes». Also the article enriches the contents of special disciplines with innovative technologies that stimulate students to speech activity.

Key words: lawyers', communicative competence, pedagogical conditions, special subjects.

Юрист у сучасному суспільстві - фахівець, здатний компетентно, у правовому полі розв'язувати соціальні конфлікти. Юридична професія пов'язана з підготовкою й оформленням значної кількості правових документів i вимагає вільного володіння юридичною термінологією, точних та чітких формулювань правових понять, логічних суджень, висновків, урахування багатозначності слів чи словосполучень. 
Значною мірою успіх справи (обгрунтування своєї позиції, аналіз й оцінка доказів тощо) залежить від професійної комунікативної майстерності i професійної комунікативної компетентності, зокрема знання принципів ведення дебатів, переговорів. Однак, як переконує практика судових засідань, «інтенсивне збільшення обсягів правотворчості і правозастосування та невміле використання комунікативних засобів призвело до деформації словесного вираження права, засилля юридичних помилок, до суб'єктивної оцінки смислу правових норм» [4]. Аналіз занять $з$ української мови за професійним спрямуванням, судової риторики, юридичного документознавства та основ сучасного діловодства, юридичної деонтології, виробничої практики у вищих юридичних навчальних закладах Вінниці, Сум, Черкас підтверджує, зокрема, відсутність умінь у студентів юридичних спеціальностей встановлювати й підтримувати міжособистісні ділові контакти.

3 огляду на це особливої актуальності набуває професійно-комунікативна підготовка майбутніх юристів у вищих навчальних закладах III-IV рівнів акредитації. Така підготовка має бути спрямована на ефективне опанування мовних засобів для вилучення, оброблення, продукування текстів професійного спрямування, що регламентовано галузевими стандартами вищої освіти.

Аналіз наукових джерел засвідчує, що окремі деонтологічні, культурологічні, моральноетичні, психологічні, порівняльно-правові, історичні аспекти юридичної діяльності досліджують С. Алексєєв, І. Бенедик, П. Біленчук, В. Горшенєв, С. Гусарев, А. Жалінський, А. Пиголкіна, О. Скакун, С. Сливка. Специфіку професійної підготовки майбутніх юристів вивчають українські (М. Криськів, А. Білоножко, В. Тюріна) і російські науковці (А. Храмцова, С. Зайцева, О. Усманова, С. Базаров, Г. Чанишева, С. Вишневська). Однак питання розгляду педагогічних умов формування комунікативної компетентності майбутніх юристів залишаються недостатньо дослідженими.

Метою статті є огляд літературних джерел і практичного досвіду щодо педагогічних умов формування комунікативної компетентності майбутніх юристів у процесі вивчення мовних і спеціальних дисциплін.

Відомий дидакт Ю. Бабанський наголошує, що ефективність педагогічного процесу залежить від умов перебігу [1, с. 123]. У науково-педагогічних дослідженнях педагогічну умову характеризують як основні внутрішні та зовнішні причини, які зумовлюють підвищення рівня якості фундаментальної підготовки майбутніх фахівців і піддаються корекції або компенсації в межах навчального процесу [3].

Специфіка педагогічних умов у нашому дослідженні детермінована не лише сутністю і змістом професійної комунікативної підготовки майбутніх юристів, а й особливостями сучасної правової ситуації в Україні. На основі аналізу соціальних потреб, освітньокваліфікаційних вимог спеціальності, аналізу робочих навчальних програм, анкетувань, бесід, проведених серед викладачів, студентів, працюючих юристів ми пропонуємо розглядати комунікативну компетентність юриста як складну, відкриту, динамічну систему, що характеризується певною метою (компетентний юрист), принципами, підходами, засобами, і включає когнітивно-комунікативний, афективно-комунікативний, поведінково-комунікативний взаємопов'язані компоненти. Узагальнення дослідницьких позицій дає підстави визначати педагогічні умови успішного формування комунікативної компетентності майбутніх юристів як суттєві внутрішні й зовнішні обставини, що зумовлюють, впливають і сприяють активному процесу опанування основ професійної комунікації. Це система органічно взаємопов'язаних психолого-педагогічних i практичних дій, спрямованих на розв'язання конкретних педагогічних завдань навчального процесу.

Аналіз наукової літератури та рефлексія досвіду викладання на юридичному факультеті Університету сучасних знань (Вінницька філія), а також досвід інших вищих юридичних навчальних закладів дали підстави сформулювати такі педагогічні умови формування комунікативної компетентності юриста: формування мотиваційно-ціннісного ставлення до здійснення професійної комунікації; збагачення змісту спеціальних дисциплін інноваційними технологіями; залучення студентів до створення текстів професійного спрямування; постійний контроль і корекція рівнів сформованості комунікативної компетентності.

У межах статті більш детально розглянемо перші дві педагогічні умови. 
Однією з визначальних причин успіху будь-якої діяльності людини психологи називають мотив. Є. Ільїн [2], В. Моляко [4], В. Паламарчук [5] достатньою мірою обгрунтували мотивацію навчальної діяльності як виникнення активності людини для задоволення відповідної потреби. Під час навчання ціннісно-мотиваційна сфера особистості отримує динамічний розвиток. В основі механізму формування навчальної мотивації $є$ вироблення єдиної структури цілей навчальної діяльності. Саме тому доведення цілей навчання до свідомості під час лекцій, практичних занять, самостійної роботи значно вмотивовує студентів. Вищеокреслене доведемо на прикладі вивчення курсу «Українська мова за професійним спрямуванням», що викладається в тісному взаємозв'язку з юридичними дисциплінами. Зокрема, питання правового статусу державної мови розглядається у взаємозалежності 3 конституційним правом України; елементи почерку, ідентифікацію голосу тієї чи тієї особистості - 3 криміналістикою; особливості створення текстових процесуальних документів - із кримінально-процесуальним та цивільно-процесуальним правом.

Окреслимо визначальні напрями комунікативної підготовки майбутніх юристів i формування мотиваційно-ціннісного ставлення до здійснення професійної комунікації. Зокрема, під час занять практикуємо створення документів 3 урахуванням особливостей законодавчого, дипломатичного, адміністративно-господарського підстилів офіційно-ділового стилю: 1) канцеляризмів: віддієслівних іменників (виконання, посилення, сприяння, збіг, обшук); дієприслівникових зворотів, особливо на початку речення (керуючись вказівками, виконуючи розпорядження, сподіваючись на взаєморозуміння); прямого порядку слів (я виконую, він заперечує); 2) фахових штампів (справу закрито, обговорювати заходи); 3) засобів, що позбавлені емоційно-експресивних відтінків.

Розглядаємо комунікацію у царині права у часі та просторі, діахронно і на синхронному зрізі, в усній та писемній формах. Для цього використовуємо зразки актових книг, художню літературу, газетні та журнальні статті, фонозаписи, відеозаписи, а також листування через мережу «Інтернет». На прикладі численних текстів ознайомлюємо студентів 3 ідентифікаційною, гносеологічною, мислетворчою, естетичною, культуроносною, номінативною, волентативною, виховною, державотворчою функціями. Закріплення знань відбувається за допомогою розроблених тестів, що мають кілька рівнів складності, включаючи творчі завдання.

Характеризуючи ознаки, класифікації та реквізити ділових документів, пропонуємо виконати низку практичних завдань на перевірку таких мовних ознак, як: правильність, точність, фаховість. Професійну лексику майбутніх юристів збагачуємо, пропонуючи в текстах знаходити невідомі слова іншомовного походження i, користуючись словниками, пояснювати їх значення та походження. Контролювати власне мовлення, збагачувати, систематизувати знання про норми літературної мови, використовуючи словникові диктанти, роботу 3 сучасними юридичними словниками та довідниками, укладання міні-словника майбутньої спеціальності, аналіз виступів юристів, підготовку повідомлень на тему: «Мовний етикет в юридичній діяльності».

Важлива педагогічна умова - збагачення змісту спеціальних дисциплін інноваційними технологіями, зокрема ігровими, діалоговими, тренінговими. Особливої актуальності набувають діалогові технології (проблемно-пошукові діалоги, навчальні дискусії, евристичні бесіди, аналіз конкретних ситуацій, пов'язані зі створенням комунікативного середовища), розширення простору співпраці за схемами: студент-студент, студент-викладач, культурою діалогу.

Розглянемо технології, що використовуються нами на заняттях із судової риторики. Як правило, студентів зацікавлюють такі завдання: 1. Уявіть, що до вашого навчального закладу завітав журналіст. Спрогнозуйте його можливі запитання про роль комунікативної культури у професії юриста та запропонуйте відповіді. 2. Змоделюйте діалог за таким сюжетом: після судового засідання ви зустрілися з державним обвинувачем і з позиції студента поспілкувалися на тему підготовки судової промови.

Для розв'язання суперечливих питань доцільними $\epsilon$ семінари-дискусії «Чи потрібно змінити Конституцію України?», «Слова - це теж вчинки» (А. Франс), «Там, де немає законів, там немає і свободи» (Дж. Локк), у ході яких відбувається формування практичного досвіду спільної участі в обговоренні й розв'язанні теоретичних і практичних проблем. Ускладнюємо завдання, використовуючи технології «Займи позицію» або «Зміни позицію», сутність яких полягає в тому, що всі учасники мають визначитися зі своєю позицією стосовно обговорюваної 
проблеми, обравши при цьому один із полярних варіантів. Викладач може на свій розсуд розподілити учасників обговорення на пари або групи, враховуючи побажання студентів. Цікавою є дискусія, в основу якої покладено не суперечливу проблему, а дві протилежні тези («Усі люди народжуються добрими» (Конфуцій) та «Люди завжди злі, поки їх не примусить до добра необхідність» (Макіавеллі).

Зростає роль ігрових технологій, що охоплюють взаємодію викладача та студентів через реалізацію певного сюжету, сприяють зняттю психологічного напруження в поведінці студента, підвищенню його мотивації, розвитку пізнавальних можливостей та інтересів, прагненню до творчої самореалізації тощо. Наприклад, під час вивчення студентами теми «Судове красномовство: жанри, специфіка» подаємо теоретичні відомості про особливості судового красномовства, роль і завдання кожного учасника судового процесу, мовні особливості промов тощо; з допомогою мультимедійних презентацій демонструємо уривки 3 реальних судових процесів, обираємо фабулу майбутнього судового процесу, що відповідатиме принципам об'єктивності та логічності. У процесі гри розвиваються такі комунікативні уміння, як: уміння ставити запитання, адекватно до ситуації і комунікативної ролі використовувати мовні засоби, швидко та правильно орієнтуватися в умовах спілкування, відповідно обираючи комунікативну стратегію й тактику.

Важливою стадією проведення гри є рефлексія, що передбачає обговорення й аналіз побаченого та почутого, надання пропозицій, зауважень, рекомендацій. Задля цього викладач може обрати так званих експертів, що слідкуватимуть за проведенням гри і занотовуватимуть зауваження для подальшого обговорення. Функція викладача при цьому - консультативнокоординуюча. Важливо не тільки помітити ті моменти, що були невдалими під час гри, а й у коректній формі висловити конструктивні пропозиції для покращення як змістового наповнення заняття, так і виконавської майстерності кожного учасника, дбаючи про відповідність соціальній і комунікативній поведінці. Під час семінарських занять можуть застосовуватися як ігри, де учасники є носіями однієї соціальної ролі (студент-студент), а також ігри, коли учасники виконують різні соціальні ролі (студент-викладач).

Здійснений аналіз переконує в необхідності формування мотиваційно-ціннісного ставлення до професійної комунікації та збагачення змісту спеціальних дисциплін інноваційними технологіями. Апробація запропонованого вище навчального матеріалу дозволяє визначити основні ціннісні орієнтації та змістові установки викладача відносно студента, що сприяють формуванню комунікативної компетентності майбутніх юристів: емпатійне ставлення до студента, що передбачає прагнення і вміння відчувати іншого, розуміти його позицію, внутрішній світ, відчувати і сприймати проблеми, переживання; діалог як бажання і вміння слухати й чути, здатність викладати навчальний матеріал у формі відповіді на запитання, які виникають у студентів, здійснювати міжособистісний діалог на основі рівності позицій, взаємодовіри й поваги. У подальших статтях маємо на меті подати детальніший аналіз апробації окреслених вище педагогічних умов.

\section{Література}

1. Бабанский Ю. К. Оптимизация процесса обучения: общедидактический аспект / Ю. К. Бабанский. - М. : Педагогика, 1997.-254 с. 2. Ильин Е. П. Мотивация и мотивы : [учеб. пособ.] / Е. П. Ильин. - СПб. : Питер, 2003. - 508 с. - (Мастера психологии). 3. Методика навчання і наукових досліджень у вищій школі : [навч. посіб. для студ., магістрів, аспірант. і викл. вищ. навч. закл.] / за ред. С. У. Гончаренка, П. М. Олійника. - К. : Вища школа, 2003. - 323 с. 4. Моляко В. О Здібності, творчість, обдарованість: теорія, методика, результати досліджень: [колективна монографія] / В. О. Моляко; О. Л. Музика (ред.); Держ. фонд фундаментальних досліджень МОН України. - Житомир : Рута, 2006. - 320 с. 5. Паламарчук В. Ф. Як виростити інтелектуала: [навч. посіб. для вчит. і керівн. шкіл] / В. Ф. Паламарчук. - Тернопіль : Навчальна книга -Богдан, 2000. $151 \mathrm{c}$. 